cells in health or disease are regarded as disturbances of an underlying homcostasis, and it is the mechanism of the latter which receives most attention. The use of radioactive tracers has given to the investigation of the formation, circulation and recirculation, and final disposal, of blood cells a new power and precision. Short-term culture of blood or marrow cells in the presence of phytohæmagglutinins has made possible chromosome analysis of normal and leukæmic cells (five papers deal with chromosome abnormalities). New surgical techniques for prolonged collection of thoracic duct lymph have made quantitative examinations of lymphocyte production possible, and the use of these, together with radioactive labelling, promises a solution of the old problem of the life history and function of the lymphocyte in the not-toodistant future (four papers deal with lymphocyte kinetics). The foregoing are some of the subjects covered by this large and varied collection of articles. Though they are, for the most part, records of new work or progress reports, and only incidentally review past work, the volume as a whole gives a good conspectus of this fertilo field of research.

\section{Architecture of the Oviduct of the Domestic Hen}

According to its gross appearance, the oviduct of the domestic hen can be divided into several parts. Romanoff has described the infundibulum, the albumen secreting region (magnum) and the isthmus, while Sato, Koso and Osaki have noted a narrow part between the infundibulum and the magnum. On the other hand, the hen's egg consists of yolk, chalaziferous layer, layers of albumen, shell membrane and the egg shell. It is known that the chalaziferous layer is formed in the oviduct before the albumen secreting region, that the major part of the albumen layer is formed in the magnum, and that the shell membrane is formed in the isthmus. Consequently, it is expected that the structure, function and the product of the oviduct will present marked differences in the various segments. Histological and cytological investigations of the hen's oviduct, however, are still limited and fail to demonstrate local specialization of the oviduct. An investigation by Kazuaki Misugi and Tadashi Katsumata, of the First Department of Anatomy, Yokohama University School of Medicine, Yokohama, describes the electron microscopical characteristics of the cells composing the main segments and correlates these with the different types of proteins forming the egg (Yokohama Medical Bulletin, 14, No. 6; December 1963). The description is confined to the electron microscopic examination of the secretory cells in an active stage of secretion and reveals that the segments are composed of different cells and show segmental specialization. This segmental morphology may be correlated with the functions of the respective segments in the formation of the egg.

\section{The Effect of Isoniazid on Protein Synthesis of Myco- bacteria}

Mrchio Tsukamura and Sunio Tsukamura of the Obuso National Sanatorium, Obu, near Nagoya, Aichi-ken, Japan, have observed the effect of isoniazid on the protein synthesis of Mycobacteria (Jap. J. Tuberc., 11, Nos. 1-4; December 1963). Their investigations show that incorporation of radioactive glutamic acid into protein is inhibited by isoniazid at a concentration of $20 \mu \mathrm{g} / \mathrm{ml}$. This means that protein synthesis in the organisms, Mycobacterium 'Jucho' and $M$. tuberculosis, is inhibited by isoniazid. The effect of this drug on the incorporation of amino-acids into protein is heterogeneous; incorporation of glutamic acid was inhibited, while incorporation of glycine and leucine was not inhibited. It was shown also that $\alpha$-ketoglutarate is converted to glutamic acid and then incorporated into protein. The former was not inhibited, but the latter was inhibited by isoniazid. It is still not clear whether the inhibition of protein synthesis is a primary effect of isoniazid. The finding that incor- poration of $\alpha$-ketoglutarate into the nucleic acid fraction was also inhibited by isoniazid makes it difficult to draw a definite conclusion. It is remarkable that the pattern of distribution into cellular fractions of radioactivity from incorporated $\alpha$-ketoglutarate differs significantly from the pattern of acetate. Most parts of radioactive acetate- $1-{ }^{14} \mathrm{C}$ were incorporated into the lipid and protein fractions, whereas only a small part of the keto acid was incorporated into the lipid fraction. However, this pattern of incorporation of the keto acid is different in M. tuberculosis from that of $M$. 'Jucho'. In $M$. tuberculosis a large amount of the keto acid could be incorporated into the lipid. It is thus probable that the pattern of lipid synthesis in $M$. tuberculosis differs from that of $M$. 'Jucho'.

\section{Australian Mineral Industry}

The Australian Bureau of Mineral Resources, Geology and Geophysics, among its other official publications, issues periodically The Australian Mineral IndustryQuarterly Review in which reasonably up-to-date information on production of selected minerals and metals and on smelter and refinery production can be sought. A recent copy (16, No. 3; March 1964) contains appropriate data (up to February 1964) on fuels (black and brown coal and petroleum); metals: aluminium, antimony, copper, gold, iron and steel, lead, manganese, monazite, tin, tungsten and zinc. In the section on industrial minerals, are included details of asbestos, gypsum, ilmenite, nitrogenous fertilizers, phosphates, rutile, sulphur and zircon. There is a keen overseas demand for Australian opal, with Japan the principal buyer, which, in the third quarter of 1963 , rose to the highest value ever recorded in a threemonthly period, nearly three-quarter million pounds sterling. Part 2 of this publication contains statistics relating to Australian production of and overseas trade in minerals and mineral products for the quarter ended September 30,1963 . In addition to the Quarterly Review, the Bureau also publishes an Annual Review; this surveys the industry as a whole and comprises a general review, review of metals and minerals, and general statistics as available for each year.

\section{Mineralogy in Japan}

Progress in research in mineralogy in Japan can be followed in periodic publications of the Mineralogical Society of Japan (Chigaku Center, Niban-chô, Chiyoda-ku, Tokyo). The Journal of the Mineralogical Society of Japan (Kôbutsugaku Zasshi) contains articles and reviews on mineralogy and allied sciences in Japanese contributed by members of the Society, and is published every four months. The Mineralogical Journal is a half-yearly publication, principally in English, and is therefore probably of wider appeal than the Journal of the Society itself; it invites contributions from everyone. In the issue recently received (4, No. I; February 1963), H Shirozu contributes a paper on structural changes of some chlorites by grinding, in particular the unusual sensitivity found in the orthohexagonal iron chlorites attributed to this cause; T. Murano discusses radioactive equilibrium in the Ningyotoge uranium ores, especially between ionium and uranium; A. Kawahara describes his X-ray studies on some alkaline amphiboles (arfvedsonite and riebeckite), with somewhat surprising optical results; K. Hayase, R. Ōtsuka and T. Mariko contribute an important paper on the magnetic properties of natural pyrrhotite; among other conclusions they draw from results of considerable experimental work on this notoriously variable species, is that naturally occurring pyrrhotite is a mixture of 'peak-' and 'Weiss-type' pyrrhotite grains and the magnetic properties of the mineral change with the ratio of one to the other occurring therein. A valuable addition to these papers is the inclusion of mineralogical abstracts from scientific papers published in Japan (1960-62). The English rendering 